\title{
Phenolic contents and antioxidant activities of extracts from young leaves of Camellia japonica L. in Jeju
}

\author{
Dong Won Jeong ${ }^{1} \cdot$ Min Young Kim ${ }^{1}$ (D) \\ 제주 동백나무 어린 잎의 페놀류 함량과 항산화 효능
}

정동원 ${ }^{1} \cdot$ 김민영 1

Received: 5 August 2017 / Accepted: 11 September 2017 / Published Online: 31 December 2017

(C) The Korean Society for Applied Biological Chemistry 2017

\begin{abstract}
This study has been performed to identify the phenolic contents and antioxidant properties of methanol and ethanol extracts of young Camellia leaves in Jeju. Total polyphenol and flavonoid contents were 74.9 and $46.1 \mathrm{mg}$ gallic acid equivalent/ $100 \mathrm{~g}$, and 30.6 and $21.4 \mathrm{mg} \mathrm{RE} / 100 \mathrm{~g}$ in the methanol and ethanol extracts, respectively. Based on $\mathrm{IC}_{50}$ values, both extracts were also found to possess potent scavenging capacities of 1,1diphenyl-2-picrylhydrazyl, nitric oxide and superoxide anion radicals, and ferrous ion chelating and reducing power activities. These results showed that young Camellia leaves is a good antioxidant source and holds promise as a natural ingredient in functional food and pharmaceutical supplement.
\end{abstract}

Keywords Antioxidant $\cdot$ Flavonoid · Jeju · Phenolic · Young Camellia leaf

\section{서 론}

산소는 생명유지를 위한 호기성 에너지 대사에 필수적이지만, 호흡을 통해 체내로 유입된 산소 일부는 산화적 스트레스를 유

Min Young Kim $(\bowtie)$

E-mail: jeffmkim@jejunu.ac.kr

${ }^{1}$ Toxicology Laboratory, Major in Biomaterials, SARI, Jeju National University, Jeju 690-756, Republic of Korea

This is an Open Access article distributed under the terms of the Creative Commons Attribution Non-Commercial License (http://creativecommons. org/licenses/by-nc/3.0/) which permits unrestricted non-commercial use, distribution, and reproduction in any medium, provided the original work is properly cited.
발하여 암이나 동맥질환 등 만성적 질병이나 노화의 원인이 되 는 활성산소종으로 전환되게 된다(Kim과 Park 2011). 최근 활 성산소종의 유리기를 제거함으로써 세포를 산화적 손상으로부 터 보호 할 수 있는 폴리페놀 등의 특정 성분을 함유하고 있는 천연 항산화 소재에 대한 관심이 증대되고 있으며 이를 발굴하 기 위한 연구 또한 꾸준히 진행되고 있다(Kim과 Seong 1999). 동백나무(Camellia japonica L.)는 차나무과에 속하는 나무로 우리나라에서 동백군락지가 주로 온대 남부의 해안 도서지방인 전남, 경남, 제주를 중심으로 많은 분포를 보이는데, 이는 기후 와 토양 조건과 연관이 깊은 것으로 생각된다. 도서, 해안지역 은 내륙지역보다 2 배 이상의 강한 바람이 부는데 이러한 바람 이 엽온을 저하시켜 한여름의 생육장애를 피하게 할 수 있고, 평균기온이 높고 강수량이 많으며 갈색 산림토로 구성되어 있 는 지역일수록 동백군락지가 형성되어 있다(Cho과 Kwack 1994). 예로부터 차나무가 없는 지역에서 활엽상록수인 동백나 무 잎을 차의 재료로 사용하여 왔는데, 동백나무 잎의 약리학 적 효과로는 건선, 인후 통증, 화상과 항균, 진경 및 알코올 흡 수 억제 등이 알려져 있으며 다양한 생리활성 성분을 함유하고 있어(Cha등, 2004; Heo 등, 2007; Choi 등, 2010) 천연 기능 성 식의약품 소재로서 이용가치가 높은 식물로 사료된다. 하지 만 동백나무의 꽃, 열매, 성엽 등의 부위(Choi 등, 2013)에 비 해 상대적으로 어린 동백나무 잎에 대한 성분 및 생리학적 활 성에 대한 연구가 미흡하고 차의 원료로 쓰이는 동백나무 잎은 그 채취시기나 부위 및 품종에 따라 효능의 차이가 발생하지만 (Kim 등, 2005; Jeong 등, 2014), 이에 대한 명확한 연구가 되 어 있지 않고 있다. 또한 체계적인 군락지별 주요성분 함량과 생리활성에 대한 연구는 국내외를 막론하고 거의 이루어지지 않 고 있어 군락지별 비교분석이 절실히 요구되나 국내 재배 지역 에 따른 동백나무 어린 잎의 생리활성에 차이가 있는지에 대한 과학적 자료 및 증거는 확보되어 있지 않은 실정이다. 특히 타 지역과 달리 독특한 기후 및 토양을 지닌 제주도에서 서식하는 
동백나무 어린 잎에 대한 연구는 전무하기에 본 연구는 제주산 동백나무 어린 잎의 부가가치 향상과 천연항산화제로서의 기능 성을 부여하기 위한 기초연구로 제주 동백나무 어린 잎 추출물 의 폴리페놀 함량 및 항산화 활성을 조사하였다.

\section{재료 및 방법}

\section{실험재료}

본 연구에서는 제주도 서귀포시 안덕면에 위치한 카멜리아힐에 서 5월초에 채취한 어린 동백나무 잎을 사용하였다. 채취한 시 료는 흐르는 물로 세척 후 증류수로 재차 세척하여 자연건조과 동결건조 과정을 거치고 시료를 분말화한 뒤 중량의 50 배 $(\mathrm{w} / \mathrm{v})$ 부피에 methanol과 ethanol을 첨가하여 $25^{\circ} \mathrm{C}, 150 \mathrm{rpm}$ 조건하 에 72 시간 동안 1 회 추출 여과하여 사용하였다. 추출액은 0.45 ìm syringe filter로 재차 여과하여 상등액을 얻은 후 감압 농축 하고, 이를 dimethyl sulfoxide로 용해하여 실험 재료로 사용하 였다.

\section{총 폴리페놀 함량}

총 폴리페놀 함량 측정(Kang과 $\mathrm{Kim} 2015)$ 은 시료에 $95 \%$ ethanol, 증류수, $50 \%$ Folin-Ciocalteu reagent를 첨가하여 반응 시킨 후 $5 \% \mathrm{Na}_{2} \mathrm{CO}_{3}$ 를 첨가하여 1 시간 동안 호일로 감싸 차광 반응 후 $725 \mathrm{~nm}$ 에서 흡광도를 측정하였다. 폴리페놀 함량은 gallic acid standard solution을 통해 표준곡선을 작성하고 그 결과를 $\mathrm{mg}$ gallic acid equivalent $(\mathrm{GAE}) / 100 \mathrm{~g}$ dried weight 로 나타내었다.

\section{총 플라보노이드 함량}

총 플라보노이드 함량(Kang과 $\mathrm{Kim}$ 2015)은 시료에 증류수, sodium nitrite $\left(\mathrm{NaNO}_{2}\right)$ 를 첨가하여 6분 동안 반응 후 $10 \%$ aluminium chloride $\left(\mathrm{AlCl}_{3}\right)$ 를 첨가하여 다시 6분간 반응시켰다. 이후 $1 \mathrm{M}$ sodium hydroxide $(\mathrm{NaOH})$, 증류수를 첨가하여 15 분 간 반응시킨 뒤 $420 \mathrm{~nm}$ 에서 흡광도를 측정하였다. 표준물질로 rutin을 사용하여 총 플라보노이드 함량 $(\mathrm{mg}$ rutin equivalent $(\mathrm{RE}) / 100 \mathrm{~g})$ 을 산출하였다.

\section{DPPH, Superoxide 및 Nitric oxide radical소거 활성}

1,1-diphenyl-2-picrylhydrazyl (DPPH) radical 소거활성(Kang과 $\mathrm{Kim} 2015$ )은 시료에 $0.4 \mathrm{mM} \mathrm{DPPH}$ solution를 첨가하여 혼합 한 후 차광하여 실온에 10 분간 반응시키고 $517 \mathrm{~nm}$ 에서 흡광도 를 측정하였다. Superoxide radical 소거능(Kim과 Kim 2011)은 시료 용액에 $50 \mathrm{mM}$ sodium carbonate buffer ( $\mathrm{pH}$ 10.5)와 3 $\mathrm{mM}$ xanthine, $3 \mathrm{mM}$ ethylenediaminetetraacetic acid, $0.75 \mathrm{mM}$ nitroblue tetrazolium, $0.15 \%$ bovine serum albumin solution를 첨가하고 10 분간 반응시킨 후 $6 \mathrm{mU} / \mathrm{mL}$ xanthine oxidase를 첨 가하여 다시 20 분간 반응시키고, $6 \mathrm{mM}$ copper chloride $(\mathrm{CuCl})$ 를 넣어 반응을 멈춘 뒤 $560 \mathrm{~nm}$ 에서 흡광도를 측정 하였다. Nitric oxide 소거 활성(Kim과 $\operatorname{Kim} 2011)$ 은 시료 용액에 10 $\mathrm{mM}$ sodium nitroprusside를 첨가한 후 상온에서 3시간 동안 반 응시키고 Griess reagent를 혼합하여 15 분이 지난 뒤 $540 \mathrm{~nm}$ 에 서 흡광도를 측정하였다. 측정된 흡광도는 시료 첨가군과 무첨
가군의 차이를 계산하여 나타내고 $50 \%$ 소거 농도 $\left(\mathrm{IC}_{50}\right)$ 를 계산 하여 용매 및 농도에 따른 radical 소거능을 비교하였다. 양성 대조군으로는 L-ascorbic acid를 사용하여 겨우살이 추출물의 radical 소거능을 비교분석하였다.

\section{Chelating 활성}

Chelating 활성(Kang과 $\operatorname{Kim}$ 2015)은 시료 추출물, $2 \mathrm{mM}$ ferrous chloride $\left(\mathrm{FeCl}_{2}\right), 5 \mathrm{mM}$ 3-(2Pyridyl)-5,6-diphenyl-1,2,4triazine-p,p'-disulfonic acid monosodium salt hydrate (ferrozine) solution를 첨가하고 10 분간 반응시킨 뒤 $562 \mathrm{~nm}$ 에서 흡광도를 측정하였다. 시료 첨가군 및 무첨가군의 흡광도 차이를 계산하 였고, ferrous ion chelating $50 \%$ 활성을 억제하는 농도 $\left(\mathrm{IC}_{50}\right)$ 를 계산하였다. 양성대조군으로 L-ascorbic acid를 이용하여 ferrous ion chelating 활성을 측정함으로써 어린 동백나무 잎 추출물의 항산화능을 비교분석하였다.

\section{환원력}

환원력(Kang과 $\mathrm{Kim}$ 2015)은 농도별 시료 용액, $0.2 \mathrm{M}$ sodium phosphate buffer ( $\mathrm{pH}$ 6.6)와 $1 \%$ potassium ferricyanide를 순 서대로 혼합하여 $50{ }^{\circ} \mathrm{C}$ 에서 20 분 동안 반응시킨 후 $10 \%$ trichloroacetic acid를 첨가하여 반응을 정지시키고, 상층액에 $0.1 \%$ ferric chloride, 증류수를 넣고 혼합하여 $700 \mathrm{~nm}$ 에서 흡 광도를 측정하였다. 시료의 농도별 흡광도는 시료 무첨가군과 흡광도 차이를 통해 흡광도를 계산하였고, $\mathrm{OD}$ 값이 0.5 에 도달 하는데 필요한 시료의 농도 $\left(\mathrm{EC}_{0.5}\right)$ 를 통해 환원력을 나타내었다. 양성대조군으로 L-ascorbic acid를 활용하여 겨우살이 추출물의 환원력을 비교분석하였다.

\section{통계방법}

모든 실험 결과는 3 회 반복 측정 후 평균값과 그의 표준편차를 나타내었다. 각 실험군의 항산화 성분 및 활성 비교는 $p<0.05$ 수준에서 Student's $t$-test로 유의성을 검증하였다.

\section{결과 및 고찰}

식물들은 열대우림기후로부터 냉대, 한대 기후까지 매우 다양한 기후에 적응하여 생육하기에 식물내부의 2 차 대사산물과 같은 유효성분들은 재배지역의 일조, 기온, 강수량 등과 토양의 산도, 비옥도 등 조건에 따라 생체 매커니즘 과정을 통해 다양하게 생성된다(Ramakrishna과 Ravishankar 2011). 식물체내의 페놀화 합물은 2차 대사산물로서 생체 내 여러 병인으로 작용되는 활 성산소종(reactive oxygen species)을 소거 및 차단하는 높은 항 산화 기능을 가지고 있어 각종 질환의 예방과 치료에 이용되고 있다(Park 등, 2012). 폴리페놀에 속하는 수용성 식물색소인 플 라보노이드 역시 항균, 항바이러스, 지질저하 작용, 면역 증강 작용, 모세혈관 강화 작용 등이 보고(Kawaguchi 등, 1997; Choi 등, 2010) 된 바 있어, 식품, 의약품, 화장품 등 많은 분 야에서 활용되고 있다(Choi 등, 2010). 페놀 화합물 함량과 항 산화 활성간의 상호작용에 대한 많은 연구들에서 알 수 있듯이 식물체가 지니고 있는 페놀 화합물의 함량을 조사함으로써 식 물유래 천연 추출물의 항산화 활성을 탐색하는 일차적인 자료 


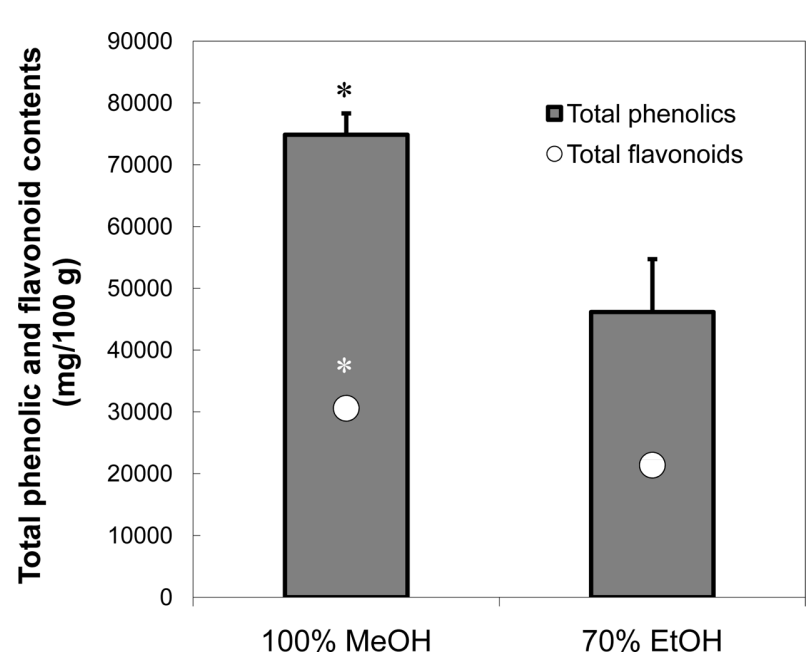

Fig. 1 Total phenolic and flavonoid contents of methanol and ethanol extracts from young leaves of Camellia japonica L. in Jeju Each value is expressed as mean $\pm \mathrm{SD}(\mathrm{n}=3)$ * Data were statistically different from the value of $70 \%$ ethanol extract $(p<0.05)$

가 될 수 있을 것으로 판단된다(Boo 등, 2009). 본 연구에서 용매별 제주 동백나무 어린 잎 추출물에 대한 총 폴리페놀과 총 플라보노이드 함량을 측정한 결과는 Fig. 1과 같다. 동백나 무 어린 잎의 총 폴리페놀은 메탄올 추출 시 $74,850 \mathrm{mg} / 100 \mathrm{~g}$ 으로 에탄올 추출물 $(46,142 \mathrm{mg} / 100 \mathrm{~g})$ 보다 유의적으로 높은 함 량을 보였는데 $(p<0.05)$, 이는 추출 용매에 대한 용해력의 차이 에 기인하는 것으로 생각된다. 또한 제주지역에서 분포하고 있 는 동백나무 어린 잎이 다른 지역에서 생육되는 어린 잎보다 상당히 높은 총 폴리페놀 함량을 지니고 있음을 알 수 있었다 (Fig. 1). 전라남도에 생육하고 있는 동백나무 어린 잎의 총 폴 리페놀 함량은 $26,088 \mathrm{mg} / 100 \mathrm{~g}$ 으로 줄기 $(7,618 \mathrm{mg} / 100 \mathrm{~g})$, 성엽 $(6,118 \mathrm{mg} / 100 \mathrm{~g})$, 꽃 $(5,647 \mathrm{mg} / 100 \mathrm{~g})$ 보다 많은 폴리페놀을 함 유하는 것으로 나타났으며(Seo과 $\mathrm{Kim} 2015)$, 경상남도에 분포 하고 있는 동백나무 어린 잎 용매 분획물은 $62.4-220.8 \mathrm{mg} / 100$ $\mathrm{g}$ 의 총 phenolic 화합물 함량을 보였다(Kim 등, 2010). 그외 전 남지역의 동백나무를 대상으로 한 다른 문헌들에서 catechin과 tannic acid 표준곡선을 이용한 총 페놀 화합물은 각각 161.77 $\mathrm{mg} / 100 \mathrm{~g}$ (Lee 등, 2005)과 $23.4 \mathrm{mg} / 100 \mathrm{~g}$ (Kim과 Han 2014) 이고, 말레이지아에 분포하고 있는 녹차(Camellia sinensis) 어 린 잎의 총 폴리페놀 함량은 $7,270 \mathrm{mg} / 100 \mathrm{~g}$ (Nor Qhairul Izzreen과 Mohd Fadzelly 2013)으로 그 함량들이 제주지역 자 생 동백나무 어린 잎에 상대적으로 낮게 나타났다. 최근 An 등 (2017)의 연구에서 내륙지역인 장흥에서 자생한 동백나무의 잎 보다 해안 지역인 완도에서 자생한 동백나무의 잎이 유용성분 의 함량 측면에 있어 보다 우수하다고 보고하였는데, 이와 같 은 총 폴리페놀 함량 차이는 동백나무 재배지 환경(기후, 토양 성질 등)과 함께 품종, 수확시기 및 추출조건(추출용매, 추출시 간 용매 등)에 따라 차이가 나는 것으로 생각된다. 본 연구에 서 총 플라보노이드 함량 역시 메탄올 추출물 $(30,577 \mathrm{mg} \mathrm{RE} /$ $100 \mathrm{~g})$ 이 에탄올 추출물 $(21,386 \mathrm{mg} / 100 \mathrm{~g})$ 에 비해 유의적으로 높 게 나타났고 $(p<0.05)$ (Fig. 1$)$, 제주지역에서 자생하는 동백나무 어린 잎이 전라남도(8,760-19,610 mg/100 g) (Kim과 Han 2014;
Seo과 $\operatorname{Kim} 2015)$ 와 경상남도(2,540-12,350 mg/100 g) (Kim 등, $2010)$ 지역에 비해 높은 총 플라보노이드 함량을 보이는 것을 알 수 있었다. 이처럼 동백나무의 식생환경(기후, 토양)에 따라 지역마다 총 플라보노이드 함량이 다른 것으로 생각되는 바 앞 으로 더 전문적이고 체계적인 연구가 필요하다 판단된다.

$\mathrm{DPPH}$ 는 진한 보라색을 띠는 안정한 free radical이고 항산화 물질을 처리했을 때 radical이 환원되어 탈색되는 원리를 이용 하여 흡광도를 측정함으로써 항산화 활성을 측정할 수 있다 (Jeong 2008). 본 실험결과 제주 동백나무 어린 잎의 농도가 증 가함에 따라 $\mathrm{DPPH}$ 소거 활성이 점진적으로 증가하였고 100 $\mathrm{ig} / \mathrm{mL}$ 농도에서 메탄올 추출물은 $91 \%$, 에탄올 추출물은 $74.1 \%$ 의 소거활성을 보였다. 같은 $100 \mu \mathrm{g} / \mathrm{mL}$ 의 농도에서 전라남도 자생 동백나무 어린 잎 활성이 $92.19 \%$ (Lee 등, 2005), 88.2\% (Seo과 $\mathrm{Kim} 2015$ )와 47.23\% (Kim과 $\operatorname{Han} 2014$ )로, 경남 지역 의 동백나무 어린 잎 활성이 $92.19 \%(\mathrm{Kim}$ 등, 2010)로 보고되 어 제주지역에서 분포하고 있는 동백나무 어린 잎의 $\mathrm{DPPH}$ radical 소거 활성이 다른 지역보다 유사하거나 우수하였다(Table 1). 또한 $\mathrm{DPPH}$ radical을 $50 \%$ 소거하는 농도 $\left(\mathrm{IC}_{50}\right)$ 값에서도 제주산 동백나무 어린 잎의 메탄올과 에탄올 추출물이 $136 \mu \mathrm{g} /$ $\mathrm{mL}$ 과 $174 \mu \mathrm{g} / \mathrm{mL}$ 로 나타나 $(p<0.05)$ (Table 1), 전라남도에서 자 생한 동백나무 잎 추출물 $(197.65 \mu \mathrm{g} / \mathrm{mL})$ (Kim과 Han 2014)과 동백오일 $(500,000 \mu \mathrm{g} / \mathrm{mL})$ (Choi 등, 2013) 보다 우수한 효능을 가지는 것으로 나타났다. 이처럼 산지에 따라 DPPH radical 소 거 활성이 다른 것은 재배지의 환경, 기후조건 등에 따라 나타 날 수 있는 차이로 추정된다. Superoxide anion radical은 반응 성이 높고 독성이 강한 radical로 노화와 관련된 산화반응의 개 시단계에 관여하고 있다. 또한, hydrogen peroxide, hydroxyl radical, singlet oxygen 등의 전구체로 작용하므로 이 radical에 대한 소거활성 측정은 시료의 항산화 물질 탐색에 효과적인 방 법으로 알려져 있다(Jin 2011; Park 등, 2012). 본 연구에서 $\mathrm{DPPH}$ radical 소거능 결과와 마찬가지로 동백나무 어린잎의 superoxide 소거능 역시 메탄올 $\left(\mathrm{IC}_{50}=238 \mu \mathrm{g} / \mathrm{mL}\right)$ 추출물이 에탄 올 $\left(\mathrm{IC}_{50}=136 \mu \mathrm{g} / \mathrm{mL}\right)$ 추출물보다 유의적으로 높게 측정되었는데 $(p<0.05)$ (Table 1), 이는 Jain 등(2011)이 보고한 녹차(Camellia sinensis $)\left(\mathrm{IC}_{50}=59,800 \mu \mathrm{g} / \mathrm{mL}\right)$ 의 superoxide radical 소거 결과보 다 우수한 것으로 나타났다. Nitric oxide는 여러 조직과 세포에 서 L-arginine으로부터 nitric oxide synthase에 의해 합성되어 혈압조절, 신경전달, 혈소판응집억제, 면역기능 등의 역할을 하 지만 과량으로 존재할 시 $\mathrm{DNA}$ 합성 억제, 각종 효소의 작용 을 억제, 세포 손상 및 염증반응을 일으키고 superoxide와 반응 하여 독성과 반응성이 높은 산화제인 peroxynitrite를 생성하는 것으로 알려져 있다(Lee등, 2014). 제주 동백나무 어린 잎 에탄 올 추출물의 $\mathrm{IC}_{50}$ 값은 $245 \mu \mathrm{g} / \mathrm{mL}$ 로 측정되어 메탄올 추출물 $(302$ $\mu \mathrm{g} / \mathrm{mL}$ )에 비해 유의적으로 뛰어난 nitric oxide 소거 활성을 보 였다 $(p<0.05)$ (Table 1). 또한 $100 \mu \mathrm{g} / \mathrm{mL}$ 농도에서 제주 동백나 무 어린 잎 추출물은 약 $53 \%$ 의 소거능을 보여 기존 문헌에서 $55 \%$ 의 소거능을 보인 녹차(Camellia sinensis) (Jain 등, 2011) 와 유사한 활성을 보인 반면, 동일농도 $(100 \mu \mathrm{g} / \mathrm{mL})$ 에서 $36.49 \%$ 소거능을 보인 전라남도 자생 동백나무 잎(Kim과 $\mathrm{Han}$ 2014)과 태국 동백나무 잎으로 만들어진 차 $\left(\mathrm{IC}_{50}=144 \mu \mathrm{g} / \mathrm{mL}\right.$ ) (Tsai 등, 2007) 보다 우수한 nitric oxide 소거 효과를 나타내었다. 식물 은 생육에 있어서 광도뿐만 아니라 온도, 습도, 토양환경, 경쟁 
Table $1 \mathrm{IC}_{50}$ value in free radical scavenging, ferrous ion chelating and reducing power properties of methanol and ethanol extracts from young leaves of Camellia japonica $\mathrm{L}$. in Jeju

\begin{tabular}{cccccc}
\hline \hline \multirow{2}{*}{ Solvent } & \multicolumn{4}{c}{$\mathrm{IC}_{50}$ value $(\mathrm{ig} / \mathrm{mL})^{1)}$} \\
\cline { 2 - 6 } & $\mathrm{DPPH}$ & Superoxide & Nitric oxide & $\begin{array}{c}\text { Chelating effect on } \\
\text { ferrous ions }\end{array}$ & Reducing power \\
\hline $100 \% \mathrm{MeOH}$ & $136 \pm 0.9^{*}$ & $238 \pm 5.8^{*}$ & $302 \pm 7.3^{*}$ & $217 \pm 8.6^{*}$ & $255 \pm 9.4^{*}$ \\
$70 \% \mathrm{EtOH}$ & $174 \pm 2.9$ & $136 \pm 3.2$ & $245 \pm 6.0$ & $262 \pm 14.1$ & $222 \pm 8.2$ \\
\hline
\end{tabular}

${ }^{1)} \mathrm{IC}_{50}$ : The effective concentration at which the antioxidant activity was $50 \% \mathrm{IC}_{50}$ was obtained by interpolation from linear regression analysis

Each values is expressed as mean \pm standard deviation $(n=3) *$ Data were statistically different from the value of $70 \%$ ethanol extract $(p<0.05)$

식생, 수분함량 등 여러 가지 다양한 환경인자가 관여하기 때 문에 지역별로 항산화 활성이 다르게 나타나는 것으로 생각된다.

$\mathrm{Fe}^{2+}, \mathrm{Cu}^{2+}$ 등과 같은 금속은 지질산화 반응을 촉매하므로 금 속의 chelating 활성이 높아질수록 촉매 감소에 따른 지질산화 반응을 억제할 수 있는데, Ferrozine 은 금속과 결합하여 색깔 이 변하는 발색제로 ferrozine 과ferrous ion의chelating 작용이 억제되는 정도를 측정함으로써 항산화 활성을 나타낸다(Kang 등, 2012). 본 연구에서 제주 동백나무 어린잎의 시료의 chelating 활성을 측정한 결과, $10-500 \mu \mathrm{g} / \mathrm{mL}$ 까지 농도 의존적 으로 그 활성이 증가함을 알 수 있었다. 또한 $\mathrm{IC}_{50}$ 값은 메탄올 추출물이 $217 \mu \mathrm{g} / \mathrm{mL}$ 로 에탄올 추출물 $(262 \mu \mathrm{g} / \mathrm{mL})$ 에 비해 우수 한 chelating 활성을 가진 것을 확인할 수 있었는데(Table 1), 차로 많이 사용되는 국화 $\left(\mathrm{IC}_{50}=900 \mu \mathrm{g} / \mathrm{mL}\right.$ ) (Woo 등, 2010)와 중국 동백나무 차 $\mathrm{IC}_{50}=1,800 \mu \mathrm{g} / \mathrm{mL}$ ) (Chan 등, 2010)에 비해 제주 동백나무 어린 잎의 chelating활성이 우수하다는 것을 알 수 있었다. 각기 다른 chelating 활성은 재배지의 토양 및 기후 특성에 의해 영향을 받는 것으로 생각된다. 환원력은 ferricferricyanide혼합물이 수소를 공여함으로써 ferrous로 전환하여 금 속물의 결합, 과산화물의 분해, 연속적인 수소 제거의 방해 등 항산화 활성에 중요한 인자로 작용한다(Siddhuraju 등, 2002; $\mathrm{Kim}$ 등, 2010). 0-500 $\mu \mathrm{g} / \mathrm{mL}$ 에서 동백나무 어린 잎 추출물에 대한 환원력을 측정한 결과, 메탄올과 에탄올 추출물 모두 50 $\mu \mathrm{g} / \mathrm{mL}$ 까지는 농도별 흡광도 증가는 미미하였으나 $100 \mu \mathrm{g} / \mathrm{mL}$ 부 터는 흡광도가 급격하게 증가하면서 환원력이 유의적으로 커지 는 것을 알 수 있었다. 또한, $700 \mathrm{~nm}$ 에서의 $\mathrm{OD}$ 값이 0.5 에 도달하기 위한 농도 $\left(\mathrm{IC}_{0.5}\right)$ 를 비교한 결과 에탄올 $(222 \mu \mathrm{g} / \mathrm{mL})$ 과 메탄올 추출물 $(255 \mu \mathrm{g} / \mathrm{mL})$ 이 유사한 수치를 나타냈고 $(p<0.05)$ (Table 1), 중국 광저우 지방의 동백나무 꽃 $\left(\mathrm{IC}_{0.5}=399 \mu \mathrm{g} / \mathrm{mL}\right)$ (Li 등, 2014)보다 높은 환원력을 나타내었다.

상기 연구결과로 보아 제주 동백나무 어린 잎의 총 폴리페놀 및 플라보노이드 함량이 증가함에 따라 항산화 활성이 증가하 는 것을 추측해 볼 수 있고, 여타 연구결과들과 비교했을 때 특 히 폴리페놀 및 플라보노이드 함량과 항산화 활성간의 높은 상 관관계를 가지고 있다는 것을 알 수 있었다(Kim 등, 2009). 이 에 따라 제주 동백나무 어린 잎의 항산화 성분 함량과 항산화 활성 $\left(\mathrm{IC}_{50}\right)$ 간의 상관관계를 분석한 결과는 Table 2 와 같다. 항 산화 활성이 증가할수록 $\mathrm{IC}_{50}$ 값이 감소하는 양상을 띄므로 총 폴리페놀 및 플라보노이드 함량과 $\mathrm{IC}_{50}$ 간에는 모두 음의 상관 관계를 보이고 있고, 모든 상관계수가 절대값 1 에 가까운 $r^{2}$ 값 을 나타내어 성분 함량이 증가함에 따라 항산화 활성이 유의적 으로 증가하는 것을 알 수 있다(Table 2). 또한 총 폴리페놀 함 량과 항산화 활성간의 상관관계에서 모두 $0.05,0.01$ 수준에서
Table 2 Correlation coefficients between antioxidant compounds and antioxidant activities of young leaves of Camellia japonica L. in Jeju

\begin{tabular}{cccccc}
\hline \hline & $\mathrm{DPPH}^{3)}$ & $\mathrm{S}^{4)}$ & $\mathrm{NO}^{5)}$ & $\mathrm{FIC}^{6)}$ & $\mathrm{RP}^{7)}$ \\
\hline $\mathrm{TPC}^{1)}$ & $-0.976^{* *}$ & $-0.856^{*}$ & $-0.970^{* *}$ & $-0.770^{*}$ & $-0.990^{* *}$ \\
$\mathrm{TFC}^{2)}$ & $-0.993^{* *}$ & $-0.906^{* *}$ & $-0.980^{* *}$ & $-0.799^{*}$ & $-0.998^{* *}$ \\
\hline
\end{tabular}

${ }^{1)}$ TPC: Total phenolic contents

${ }^{2)}$ TFC: Total flavonoid contents

${ }^{3}$ DPPH: DPPH radical scavenging activity

${ }^{4} \mathrm{~S}$ : Superoxide scavenging activity

${ }^{5)} \mathrm{NO}$ : Nitric oxide scavenging activity

${ }^{6}$ FIC: Ferrous ion chelating activity

${ }^{7)} \mathrm{RP}$ : Reducing power activity

$p$-Values of $<0.05^{*}$ and $<0.01^{* *}$ were considered highly statistically significant

유의함을 나타냈는데, 총 폴리페놀 함량과 환원력 간의 상관관 계에서 $r^{2}=-0.990$ 로 가장 높은 상관관계를 나타내었다(Table 2). 플라보노이드 함량과 항산화 활성간의 상관관계 역시 $\mathrm{r}^{2}$ 값이 chelating 활성을 제외하고는 모두 0.9 이상으로 매우 높은 상 관관계를 보였다. 이상의 결과를 종합해 보면, 총 폴리페놀 및 플라보노이드가 항산화 활성의 주요 물질로 작용하여 항산화력 에 영향을 미친다는 것을 알 수 있었고, 제주 동백나무 어린 잎 을 항산화 활성을 보유한 기능성 소재로서의 활용하기 위한 기 초자료로 이용될 수 있을 것으로 판단된다.

\section{초 록}

본 연구는 제주 동백나무 어린 잎 메탄올 추출물과 에탄올 추 출물의 페놀류 함량 및 항산화 활성에 대한 연구를 진행하였다. 메탄올 추출물과 에탄올 추출물의 총 폴리페놀과 플라보노이드 함량은 각각 74.9 과 $46.1 \mathrm{mg} \mathrm{GAE} / 100 \mathrm{~g}$ 및 30.6 과 $21.4 \mathrm{mg}$ $\mathrm{RE} / 100 \mathrm{~g}$ 이었다. 또한 추출물들은 $\mathrm{DPPH}$, superoxide와 nitric oxide 라디컬 소거능, chelating 및 환원력을 가지는 것으로 나 타났다. 이 결과들로 동백나무 어린 잎이 높은 항산화 효능을 가지고 있음을 알 수 있었으며, 차후 기능성 식품 및 약물 소 재로서의 가능성을 검토할 필요가 있다.

Keywords 동백어린잎 - 제주 · 플라보노이드 · 페놀 · 항산화

감사의 글 이 논문은 2014년(NRF-2014R1A1A2056292)과 2016년도 (2016R1A6A1A03012862) 정부(교육부)의 재원으로 한국연구재단의 지원을 받아 수행된 연구사업임. 


\section{References}

An K, Park SY, Lee JY, Moon JH, Kim EI (2017) Comparison of the phenolic contents of Camellia japonica leaves collected in different regions. J Kor Tea 23(2): 63-67

Boo HO, Lee HH, Lee JW, Hwang SJ, Park SU (2009) Different of total phenolics and flavonoids, radical scavenging activities and nitrite scavenging effects of Momordica charantia L. according to cultivars. Korean J Med Crop Sci 17: 15-20

Cha YJ, Lee JW, Kim JH, Park MH, Lee SY (2004) Major components of teas manufactured with leaf and flower of Korean native Camellia japonica L. Kor J Medi Crop Sci 12: 183-190

Chan EWC, Lim YY, Chong KL, Tan JBL, Wong SK (2010) Antioxidant properties of tropical and temperate herbal teas. J Food Comp Anal 23: 185-189

Cho KH, Kwack BH (1994) Ecological significance for wild distributions of Cymbidium goeringii and Camellia japonica in Korea. J Kor Flower Res Soc 3(1):25-34

Choi BD, Jeon HS, Lee YS, Joo EY, Kim NW (2010) Analysis of the contents and physiological activities of Calystegia japonica leaf extracts. Kor J Food Sci Tech 42: 250-255

Choi MH, Min MJ, Oh DS, Shin HJ (2013) Antimicrobial and antioxidant activity of Camellia japonica extracts for cosmetic applications. KSBB J 28: 99-105

Heo ID, Seo HJ, Kim JD (2007) Anti-angiogenic and anti-cell adhesion effect of the Camellia japonica flower extract. J Life Sci 17: 1152-1156

Jain DP, Pancholi SS, Patel R (2011) Synergistic antioxidant activity of green tea with some herbs. J Adva Phar Tech Research 2: 177-183

Jeong MJ (2008) Antioxidative and antiallergic effects of aronia (Aronia melanocarpa) extract. J Kor Soc Food Sci Nutr 37: 1109-1113

Jeong YS, You YH, Jun WJ (2014) Anti-obesity effects of extracts from young Akebia quinata D. leaves. J Kor Soc Food Sci Nutr 43: 200-206

Jin SY (2011) Study on antioxidant activities of extracts from different parts of Korean and Iranian pomegranates. J Korean Soc Food Sci Nutr 40: 1063-1072

Kang DH, Kim MY (2015) Comparative phenolic composition and antioxidant properties of honey and honeycomb extracts. J Life Sci 25: $1169-1175$

Kang KM, No HK, Park CS, Youn KS, Hong JH, Lee SH (2012) Antioxidative activity of Kalopanax pictus shoot extracted using different extraction methods. J Kor Soc Food Sci Nutr 41: 1686-1692

Kawaguchi K, Mizuno T, Aida K, Uchino K (1997) Hesperidin as an inhibitor of lipases from porcine pancreas and Pseudomonas. Biosci Biotechnol Biochem 61: 102-104

Kim BS, Choi OJ, Shim KH (2005) Properties of chemical components of Camellia japonica L. leaves according to picking time. J Kor Soc Food Sci Nutr 34: 681-686

Kim HK, Lee MY, Hong IP, Choi YS, Kim NS, Lee ML, Lee SC (2010) Antioxidant and antimicrobial capacity of several monofloral honey correlation with phenolic and flavonoid contents. Kor J Apic 25: 275282

Kim HS, Seong LS (1999) Induction of erythromycin by virginiamycin inducing factor, Virginiae Butanolide C. Korean J Biotechnol Bioeng 14: 682-687

Kim JH, Jeong GH, Shim KH (2010) Antioxidative and anticancer activities of various solvent fractions from the leaf of Camellia japonica L. Kor J Food Pres 17: 267-274

Kim JH, Kim MY (2011) Effect of citrus waste substrate on the production of bioactive component, and antioxidant and antitumor activity of Grifola frondosa. Life Sci J 8: 564-571

Kim MJ, Park EJ (2011) Feature analysis of different in vitro antioxidant capacity assays and their application to fruit and vegetable samples. J Kor Soc Food Sci Nutr 40(7): 1053-1062

Kim YD, Mahinda S, Koh KS, Jeon YJ, Kim SH (2009) Reactive oxygen species scavenging activity of jeju native citrus peel during maturation. J Kor Soc Food Sci Nutr 4: 462-469

Kim YR, Han JS (2014) Antimicrobial effects of Camellia japonica leaf extract on skin disease-related microorganisms and its antioxidative activity. J Invest Cosmetol 10(1): 13-19

Lee BG, Kim JH, Ham SG, Lee CE (2014) Study on biological activities of extracts for cosmeceutical development from Lagerstroemia indica L. branch. Kor J of Plant Reso 27: 29-34

Lee SY, Hwang EJ, Kim GH, Choi YB, Lim CY, Kim SM (2005) Antifungal and antioxidant activities of extracts from leaves and flowers of Camellia japonica L. Korean J Medicinal Crop Sci 13(3): 93-100

Li AN, Li S, Li HB, Xu DP, Xu XR, Chen F (2014) Total phenolic contents and antioxidant capacities of 51 edible and wild flowers. J Func Food 6: 319-330

Nor Qhairul Izzreen MN, Mohd Fadzelly AB (2013) Phytochemicals and antioxidant properties of different parts of Camellia sinensis leaves from Sabah Tea Plantation in Sabah, Malaysia. Int. Food Res J 20(1): 307-312

Park MR, Yoo C, Chang YN, Ahn BY (2012) Change of total polyphenol content of fermented Gastrodia elata Blume and radical scavenging. Kor J Plant Reso 25: 379-386

Ramakrishna A, Ravishankar GA (2011) Influence of abiotic stress signals on secondary metabolites in plants. Plant Signal. Behav 6: 1720-1731

Seo Y, Kim C (2015) Fusion-complex activity of Camellia extract. J Digital Conv 13: 431-436

Siddhuraju P, Mohan PS, Becker K (2002) Studies on the antioxidant activity of indian laburnum(Cassia fistula L.):a preliminary assessment of crude extracts from stem bark, leaves, flowers and fruit pulp. Food Chem 97: $61-67$

Tsai PJ, Tsai TH, Yu CH, Ho SC (2007) Comparison of NO-scavenging and NO-suppressing activities of different herbal teas with those of green tea. Food Chem 103: 181-187

Woo JH, Shin SL, Lee CH (2010) Antioxidant effects of ethanol extracts from flower species of compositae plant. J Kor Soc Food Sci Nutr 39(2): 159_ 164 